\title{
Comparison of Errors of 35 Weight Estimation Formulae in a Standard Collective
}

\author{
Vergleich der Fehler von 35 Gewichtsschätzungsformeln in einem Normkollektiv
}

Authors

Affiliation
M. Hoopmann, K. O. Kagan, A. Sauter, H. Abele, P. Wagner

Department of Obstetrics and Gynecology, University of Tübingen, Tübingen, Germany

\begin{abstract}
Key words
- biometry

- foetal weight estimation

- regression formula

Schlüsselwörter

- Biometrie

- fetale Gewichtsschätzung

- Regressionsformel
\end{abstract}

Deutsche Version unter: http://dx.doi.org/ 10.1055/s-0042-118598

received $\quad$ 16.7.2016 revised 5.10.2016 accepted 5.10.2016

\section{Bibliography}

DOI http://dx.doi.org/

10.1055/s-0042-118598

Geburtsh Frauenheilk 2016; 76:

1172-1179 @ Georg Thieme

Verlag KG Stuttgart - New York . ISSN 0016-5751

\section{Correspondence}

Dr. Markus Hoopmann

University of Tübingen

Department of Obstetrics

and Gynecology

Calwer Straße 7

72076 Tübingen

Germany

MHoopmann@gmx.de

\section{Abstract \\ $\nabla$}

Issue: The estimation of foetal weight is an integral part of prenatal care and obstetric routine. In spite of its known susceptibility to errors in cases of underweight or overweight babies, important obstetric decisions depend on it. In the present contribution we have examined the accuracy and error distribution of 35 weight estimation formulae within the normal weight range of 2500$4000 \mathrm{~g}$. The aim of the study was to identify the weight estimation formulae with the best possible correspondence to the requirements of clinical routine.

Materials and Methods: 35 clinically established weight estimation formulae were analysed in 3416 foetuses with weights between 2500 and $4000 \mathrm{~g}$. For this we determined and compared the mean percentage error (MPE), the mean absolute percentage error (MAPE), and the proportions of estimates within the error ranges of 5 , 10, 20 and 30\%. In addition, separate regression lines were calculated for the relationship between estimated and actual birth weights for the weight range $2500-4000 \mathrm{~g}$. The formulae were thus examined for possible inhomogeneities.

Results: The lowest MPE were achieved with the Hadlock III and V formulae (0.8\%, STW $9.2 \%$ or, respectively, $-0.8 \%$, STW $10.0 \%)$. The lowest absolute error $(6.6 \%)$ as well as the most favourable frequency distribution in cases below $5 \%$ and $10 \%$ error ( 43.9 and 77.5 ) were seen for the Halaska formula. In graphic representations of the regression lines, 16 formulae revealed a weight overestimation in the lower weight range and an underestimation in the upper range. 14 formulae gave underestimations and merely 5 gave overestimations over the entire tested weight range. Conclusion: The majority of the tested formulae gave underestimations of the actual birth weight over the entire weight range or at least in the upper weight range. This result supports the cur-

\section{Zusammenfassung \\ $\nabla$}

Fragestellung: Die fetale Gewichtsschätzung ist integraler Bestandteil der Schwangerenvorsorge und des geburtshilflichen Alltags. Trotz ihrer bei unter- und übergewichtigen Kindern bekannten Fehleranfälligkeit, hängen wichtige geburtshilfliche Entscheidungen von ihr ab. In der vorliegenden Arbeit wird die Genauigkeit und die Fehlerverteilung von 35 Gewichtsformeln innerhalb des normalen Gewichtsbereichs von 2500-4000 g untersucht. Ziel der Untersuchung war es, Gewichtsformeln zu finden, die den Anforderungen des klinischen Alltags bestmöglich entsprechen. Material und Methodik: 35 klinisch etablierte Gewichtsschätzformeln wurden an 3416 Feten mit einem Gewicht zwischen 2500 und $4000 \mathrm{~g}$ analysiert. Hierbei wurden der mittlere prozentuale Fehler (MPF), der mittlere absolute prozentuale Fehler (MAPF), der Anteil der Schätzungen innerhalb eines Fehlerbereichs von 5, 10, 20 und $30 \%$ ermittelt und verglichen. Darüber hinaus wurden für den Zusammenhang von Schätz- zu tatsächlichem Geburtsgewicht getrennte Regressionsgeraden für den Gewichtsbereich 2500$4000 \mathrm{~g}$ berechnet. Die Formeln wurden somit auf eine mögliche Inhomogenität überprüft.

Ergebnisse: Der kleinste MPF wurde mittels den Hadlock-III- und -V-Formeln erzielt (0,8\%, STW 9,2\% bzw. $-0,8 \%$, STW 10,0\%). Den geringsten absoluten Fehler (6,6\%) sowie die günstigste Häufigkeitsverteilung bei Fällen unter 5\% und 10\% Fehler (43,9 und 77,5) wies die Halaska-Formel auf. In der grafischen Darstellung der Regressionsgeraden zeigen 16 Formeln eine Gewichtsüberschätzung im unteren Gewichtsbereich und eine -unterschätzung im oberen Bereich. 14 Formeln unterschätzen und lediglich 5 Formeln überschätzen über den getesteten Gewichtsbereich.

Schlussfolgerung: Die Mehrheit der Formeln unterschätzt im vollständigen oder zumindest oberen Gewichtsbereich das tatsächliche Geburts- 
rent strategy of a two-stage weight estimation in which a formula is first chosen after a pre-estimation of the weight range. gewicht. Die Ergebnisse unterstützen aktuelle Ansätze eines 2stufigen Vorgehens der Gewichtsschätzung, bei der die Formel erst nach Voreinschätzung des Gewichtsbereichs gewählt wird.

\section{Introduction}

For almost 4 decades foetal biometrics have been an integral part of established prenatal care according to maternity policy guidelines. Besides bodily integrity, biometry serves to estimate foetal weight and thus the age-appropriate development. While the first formulae for weight estimation were based solely on measurement of the biparietal diameter (BPD), the further development of numerous formulae based on combinations of biometric markers then led to an advantage over clinical estimation methods such as inspection and palpation [1-5].

For the great majority of weight estimation formulae it holds that they have been developed by means of regression analyses based on relatively small collectives of average term infants. The mean percentage error (MPE) as well as the mean absolute percentage error (MAPE) of the formulae depend on the weight itself. It is thus not surprising both for underweight infants or, respectively, pre-term infants as well as for infants with macrosomia, that the weight estimations can exhibit a clinically relevant error susceptibility [6-8]. However, it is just this delineation of the normal weight collective from the abnormally under- or overweight fetuses that is of decisive importance for the prenatal and obstetric management. Interuterine growth retardation as well as macrosomia carry significant risks for not only neonatal but also for maternal morbidity and mortality [9-11]. A differentiation from the normal collective can only be made when at least the weight estimation can reliably be classified in this range. The spread of this weight range with 2500 to $4000 \mathrm{~g}$ is, however, considered to be very wide. It is thus of interest as to which weight estimation formula exhibits not only the lowest but also the most stable errors within this range or, respectively, the largest independence on the weight range of the infant.

Accordingly, in this study we have examined by means of linear regressions how and to what extent deviations between the estimated weight and the actual birth weight in the range 2500 to $4000 \mathrm{~g}$ vary and which estimation formula exhibits the lowest constant estimation error in this situation.

\section{Materials and Methods}

\section{Description of the study collective}

For this retrospective study the perinatal database of the Department of Obstetrics and Gynecology at the University of Tübingen was searched for live births with a birth weight between 2500 and $4000 \mathrm{~g}$ in the period from 2010 to 2014 . Infants with structural malformations of chromosomal aberrations were excluded from the analysis.

\section{Conducting the biometric study}

In the framework of routine care in our perinatal centre, each pregnant woman undergoes an untrasound scan close to term. This examination is mainly intended to confirm the position of the infant, to estimate the amount of amniotic fluid and to determine the estimated foetal weight (EFW) on the basis of the usual biometry-based weight estimation formulae. The biparietal (BPD) and occipito-frontal diameters (OFD) of the head are mea- sured at the level of the transventricular plane from the outer bone margin to the outer bone margin on the opposite side. Head circumference (HC) was either determined directly by means of the ellipse or trace function or calculated from the distances $(\mathrm{HC}=2.325 \times[\mathrm{OFD} 2+\mathrm{BPD} 2] 1 / 2)[12]$. The foetal abdomen was measured by means of its transverse and anterior-posterior diameters (ATD, APD) at the level of the stomach and the umbilical vein-ductus venosus complex. The abdominal circumference was calculated from these values $(\mathrm{AC}=\pi \times[\mathrm{ATD}+\mathrm{APD} / 2])$. The femural length (FL) is measured as the distance between the diaphyses. The individual measurements, the estimated foetal weight (EFW) as well as the obstetrically relevant maternal characteristics were stored in the perinatal database. The birth weight (BW) was determined immediately after delivery by the responsible midwife, obstetrician or neonatologist and documented. For each of the included pregnancies the last ultrasound examination prior to delivery in which at least one measurement of each BPD, OFD, ATD, APD and FL was carried out was documented. Pregnancies with incomplete measurements or for which the last measurement was taken more than 7 days prior to delivery were excluded from the study. Each pregnancy was included only once in the study.

\section{Statistical analysis}

In each included case the EFW was determined by means of the published formulae according to Birnholz, Combs, Campbell, Ferrero, Hadlock, Halaska, Hansmann, Hart, Higginbottom, Jordaan, Persson, Merz, Mielke, Ott, Rose and McCallum, Sabbagha, Schild, Schillinger, Scott, Shepard, Shinozuka, Siemer, Thurnau, Vintzileos, Warsof, Weiner and Woo [3-5,13-38]. The corresponding formulae are listed in $\bigcirc$ Table 1 . The accuracies of the various formulae were determined and compared by means of the mean percentage error $(\mathrm{MPE}=[\mathrm{EFW}-\mathrm{BW}] / \mathrm{BW} \times 100)$ and the mean absolute percentage error $(\mathrm{MAPE}=|(\mathrm{EFW}-\mathrm{BW})| / \mathrm{BW} \times 100)$. Hereby the MPE represents the systematic error of the formula. Its standard deviation (SD) reflects the random elements in the prediction error. The $95 \%$ confidence intervals (CI) for the MPE were calculated and were used to test for a significant deviation against 0 . For each estimation formula the proportions of the weight estimations with percentage errors of $\leq 5, \leq 10, \leq 20$ and $\leq 30 \%$ were calculated.

The relationship between the estimated and the actual birth weights was examined by means of a liner regression analysis. The extent of the estimation error in dependence on the actual birth weight could be estimated with the help of the regression.

\section{Results}

\section{Demographic characteristics}

Altogether 3416 pregnancies were included in the study after consideration of the inclusion criteria. The average age of the mothers amounted to 31.1 years. The average weight of the mothers was $76.9 \mathrm{~kg}$ (SD $\pm 14.7 \mathrm{~kg}$, range $31.0-160.2 \mathrm{~kg}$ ). On average the gestational age at birth was $39+1$ weeks (interquartile range [IQR] $38+0-40+1 \mathrm{SSW}$ ). The gender distribution was balanced. The average weight at birth amounted to $3181 \mathrm{~g}$. In the 
Table 1 Survey of the 35 weight estimation formulae.

\begin{tabular}{|c|c|c|}
\hline Author & Data & Formula \\
\hline Birnholz [13] & BPD, OFD, ATD & $3.42928 \times(\mathrm{BPD} \times \mathrm{OFD} / 1.264)^{0.5} \times \mathrm{AD}^{2} / 1000+41.218[\mathrm{~g}, \mathrm{~mm}]$ \\
\hline Combs [14] & $\mathrm{HC}, \mathrm{AC}, \mathrm{FL}$ & $0.23718 \times \mathrm{AC}^{2} \times \mathrm{FL}+0.03312 \times \mathrm{HC}^{3}[\mathrm{~g}, \mathrm{~cm}]$ \\
\hline Campbell [15] & AC & $\mathrm{e}^{\left(-4.564+0.282 \times \mathrm{AC}-0.00331 \times \mathrm{AC}^{2}\right)[\mathrm{kg}, \mathrm{cm}]}$ \\
\hline Ferrero [16] & AC, FL & $10^{\left(0.77125+0.13244 \times \mathrm{AC}-0.12996 \times \mathrm{FL}-1.73588 \times \mathrm{AC} \mathrm{C}^{2} / 1000+2.18984 \times \mathrm{FL} / \mathrm{AC}\right)}[\mathrm{g}, \mathrm{Cm}]$ \\
\hline Hadlock I [4] & $\mathrm{BPD}, \mathrm{HC}, \mathrm{AC}, \mathrm{FL}$ & $10^{(1.3596+0.0064 \times \mathrm{HC}+0.0424 \times \mathrm{AC}+0.174 \times \mathrm{FL}+0.00061 \times \mathrm{BPD} \times \mathrm{AC}-0.00386 \times \mathrm{AC} \times \mathrm{FL})}[\mathrm{g}, \mathrm{cm}]$ \\
\hline Hadlock II [4] & $\mathrm{AC}, \mathrm{FL}$ & $10^{(1.304+0.05281 \times \mathrm{AC}+0.1938 \times \mathrm{FL}-0.004 \times \mathrm{AC} \times \mathrm{FL})}[\mathrm{g}, \mathrm{Cm}]$ \\
\hline Hadlock III [4] & $\mathrm{BPD}, \mathrm{AC}, \mathrm{FL}$ & $10^{(1.335-0.0034 \times \mathrm{AC} \times \mathrm{FL}+0.0316 \times \mathrm{BPD}+0.0457 \times \mathrm{AC}+0.1623 \times \mathrm{FL})[\mathrm{g}, \mathrm{cm}]}$ \\
\hline Hadlock IV [4] & $\mathrm{HC}, \mathrm{AC}, \mathrm{FL}$ & $10^{(1.326-0.00326 \times \mathrm{AC} \times \mathrm{FL}+0.0107 \times \mathrm{HC}+0.0438 \times \mathrm{AC}+0.158 \times \mathrm{FL})}[\mathrm{g}, \mathrm{cm}]$ \\
\hline Hadlock V [5] & $\mathrm{BPD}, \mathrm{AC}$ & $10^{\left(1.1134+0.05845 \times \mathrm{AC}-0.000604 \times \mathrm{AC}^{2}-0.007365 \times \mathrm{BPD}^{2}+0.000595 \times \mathrm{BPD} \times \mathrm{AC}+0.1694 \times \mathrm{BPD}\right)}[\mathrm{g}, \mathrm{cm}]$ \\
\hline Hadlock VI [5] & $\mathrm{HC}, \mathrm{AC}, \mathrm{FL}$ & $10^{\left(1.5662-0.0108 \times \mathrm{HC}+0.0468 \times \mathrm{AC}+0.171 \times \mathrm{FL}+0.00034 \times \mathrm{HC}^{2}-0.0003685 \times \mathrm{AC} \times \mathrm{FL}\right)}[\mathrm{g}, \mathrm{cm}]$ \\
\hline Halaska [17] & $\mathrm{BPD}, \mathrm{AC}, \mathrm{FL}$ & $10^{\left(0.64041 \times \mathrm{BPD}-0.03257 \times \mathrm{BPD}^{2}+0.00154 \times \mathrm{AC} \times \mathrm{FL}\right)}[\mathrm{g}, \mathrm{cm}]$ \\
\hline Hansmann [18] & $\mathrm{BPD}, \mathrm{AD}, \mathrm{GA}$, & $\begin{array}{l}-0.001665958 \times A D^{3}+0.4133629 \times A D^{2}-0.5580294 \times A D-0.01231535 \times B^{2} D^{3}+3.702 \times B P D^{2}-330.1811 \times B P D \\
-0.4937199 \times(G A+1)^{3}+55.958061 \times(G A+1)^{2}-2034.3901 \times(G A+1)+32768.19[\mathrm{~g}, \mathrm{~mm}]\end{array}$ \\
\hline Higginbottom [20] & AC & $0.0816 \times \mathrm{AC}^{3}[\mathrm{~g}, \mathrm{~cm}]$ \\
\hline Jordaan [21] & $\mathrm{BPD}, \mathrm{HC}, \mathrm{AC}$ & $10^{(2.3231+0.02904 \times \mathrm{AC}+0.0079 \times \mathrm{HC}-0.0058 \times \mathrm{BPD})}[\mathrm{kg}, \mathrm{cm}]$ \\
\hline Merz। [22] & $\mathrm{BPD}, \mathrm{AC}$ & $-3200.40479+157.07186 \times \mathrm{AC}+15.90391 \times \mathrm{BPD} \times \mathrm{BPD}[\mathrm{g}, \mathrm{cm}]$ \\
\hline Merz II [22] & $\mathrm{AC}$ & $0.1 \times \mathrm{AC}^{3}[\mathrm{~g}, \mathrm{~cm}]$ \\
\hline Ott [26] & $\mathrm{HC}, \mathrm{AC}, \mathrm{FL}$ & $10^{(-2.0661+0.04355 \times \mathrm{HC}+0.05394 \times \mathrm{AC}-0.0008582 \times \mathrm{HC} \times \mathrm{AC}+1.2594 \times \mathrm{FL} / \mathrm{AC})}[\mathrm{kg}, \mathrm{cm}]$ \\
\hline $\begin{array}{l}\text { Rose-McCallum } \\
{[27]}\end{array}$ & $\mathrm{BPD}, \mathrm{AD}, \mathrm{FL}$ & $\mathrm{e}^{(0.143 \times[\mathrm{BPD}+\mathrm{AD}+\mathrm{FL}]+4.198)}[\mathrm{g}, \mathrm{cm}]$ \\
\hline Sabbagha [28] & $\mathrm{GA}, \mathrm{HC}, \mathrm{AC}, \mathrm{FL}$ & $-55.3-16.35 \times(\mathrm{GA}+\mathrm{HC}+2 \times \mathrm{AC}+\mathrm{FL})+0.25838 \times(\mathrm{GA}+\mathrm{HC}+2 \times \mathrm{AC}+\mathrm{FL})^{2}[\mathrm{~g}, \mathrm{~cm}]$ \\
\hline Schild I [29] & $\begin{array}{l}\text { female } \\
\text { BPD, AC, FL }\end{array}$ & $-4035.275+1.143 \times \mathrm{BPD}^{3}+1159.878 \times \mathrm{AC}^{0.5}+10.079 \times \mathrm{FL}^{3}-81.277 \times \mathrm{FL}^{2}[\mathrm{~g}, \mathrm{~cm}]$ \\
\hline Schild I [29] & $\begin{array}{l}\text { male } \\
\mathrm{BPD}, \mathrm{HC}, \mathrm{AC}, \mathrm{FL}\end{array}$ & $1913.853 \times \log 10(\mathrm{BPD})+0.01323 \times \mathrm{HC}^{3}+55.532 \times \mathrm{AC}^{2}-13602.664 \times \mathrm{AC}^{0.5}-0.721 \times \mathrm{AC}^{3}+2.31 \times \mathrm{FL}^{3}[\mathrm{~g}, \mathrm{~cm}]$ \\
\hline Schillinger [30] & BPD, ATD & $397.7 \times \mathrm{BPD}+\mathrm{ATD}-4387[\mathrm{~g}, \mathrm{~cm}]$ \\
\hline Shepard [32] & $\mathrm{BPD}, \mathrm{AC}$ & $10^{(-1.7492+0.166 \times \mathrm{BPD}+0.046 \times \mathrm{AC}-0.002546 \times \mathrm{AC} \times \mathrm{BPD})}[\mathrm{kg}, \mathrm{cm}]$ \\
\hline Shinozouka [33] & $\mathrm{BPD}, \mathrm{AC}, \mathrm{FL}$ & $1.07 \times \mathrm{BPD}^{3}+3.42 \times \mathrm{ATD}^{2} \times \mathrm{FL}[\mathrm{g}, \mathrm{cm}]$ \\
\hline Warsof [3] & $\mathrm{BPD}, \mathrm{AC}$ & $10^{\left(-1.599+0.144 \times \mathrm{BPD}+0.032 \times \mathrm{AC}-0.000111 \times \mathrm{BPD}^{2} \times \mathrm{AC}\right)}[\mathrm{kg}, \mathrm{cm}]$ \\
\hline Woo [38] & $\mathrm{BPD}, \mathrm{AC}, \mathrm{FL}$ & $10^{(1,13705+0,15549 \times \mathrm{BPD}+0.0464 \times \mathrm{AC}-0.00279682 \times \mathrm{BPD} \times \mathrm{AC}+0.037769 \times \mathrm{FL}-0.000494529 \times \mathrm{AC} \times \mathrm{FL})}[\mathrm{g}, \mathrm{cm}]$ \\
\hline Vinzeleos [36] & $\mathrm{BPD}, \mathrm{AC}$ & $10^{(1.879+0.084 \times \mathrm{BPD}+0.026 \times \mathrm{AC})}[\mathrm{g}, \mathrm{cm}]$ \\
\hline Persson [23] & $\mathrm{BPD}, \mathrm{AD}, \mathrm{FL}$ & $\mathrm{BPD}^{0.972} \times([\mathrm{AD} 1+\mathrm{AD} 2] / 2)^{1.743} \times \mathrm{FL}^{0.367} \times 10^{(-2.646)}[\mathrm{g}, \mathrm{cm}]$ \\
\hline Schild II [39] & $\mathrm{HC}, \mathrm{AC}, \mathrm{FL}$ & $5381.193+150.324 \times \mathrm{HC}+2.069 \times \mathrm{FL}^{3}+0.0232 \times \mathrm{AC}^{3}-6235.478 \times \mathrm{LOG}(\mathrm{HC})[\mathrm{g}, \mathrm{cm}]$ \\
\hline Scott [31] & $\mathrm{HC}, \mathrm{AC}, \mathrm{FL}$ & $10^{(0.66 \times \operatorname{LOG}(\mathrm{HC})+1.04 \times \operatorname{LOG}(\mathrm{AC})+0.985 \times \operatorname{LOG}(\mathrm{FL}))}[\mathrm{g}, \mathrm{Cm}]$ \\
\hline Siemer [34] & $\mathrm{BPD}, \mathrm{AC}, \mathrm{FL}$ & $-5948.336+2101.261 \times \mathrm{LN}(\mathrm{AC})+15.613 \times \mathrm{FL}^{2}+0.0577 \times \mathrm{BPD}^{3}[\mathrm{~g}, \mathrm{~cm}]$ \\
\hline Thurnau [35] & $\mathrm{BPD}, \mathrm{AC}$ & $(9-337 \times B P D \times A C)-229[\mathrm{~g}, \mathrm{~cm}]$ \\
\hline Weiner I [37] & $\mathrm{HC}, \mathrm{AC}, \mathrm{FL}$ & $10^{(1.6961+0.02253 \times \mathrm{HC}+0.01645 \times \mathrm{AC}+0.06439 \times \mathrm{FL})}[\mathrm{g}, \mathrm{cm}]$ \\
\hline Weiner II [37] & $\mathrm{HC}, \mathrm{AC}$ & $10^{(1.6575+0.04035 \times \mathrm{HC}+0.01285 \times \mathrm{AC})}[\mathrm{g}, \mathrm{cm}]$ \\
\hline Mielke I [24] & BPD, ATD, FL & $\mathrm{e}^{\left(3.067510+0.01677 \times \mathrm{BPD}+0.000412 \times \mathrm{ATD}^{2}+0.040611 \times \mathrm{FL}-0.000000006027957 \times \mathrm{BPD}^{2} \times \mathrm{ATD}^{2}-0.000005086 \times \mathrm{ATD}^{2} \times \mathrm{FL}\right)}[\mathrm{g}, \mathrm{cm}]$ \\
\hline Mielke II [25] & BPD, ATD, FL & $\mathrm{e}^{\left(3.704706+0.033276 \times \mathrm{BPD}+0.000093048 \times \mathrm{ATD}^{2}+0.010570 \times \mathrm{FL}-0.00000002477864 \times \mathrm{BPD}^{2} \times \mathrm{ATD}^{2}+0.000002009 \times \mathrm{ATD}^{2} \times \mathrm{FL}\right)}[\mathrm{g}, \mathrm{Cm}]$ \\
\hline
\end{tabular}

$\mathrm{AC}=$ abdominal circumference, $\mathrm{HC}=$ head circumference, $\mathrm{FL}=$ femur length, $\mathrm{BPD}=$ biparietal diameter, $\mathrm{AD}=$ abdominal diameter, $\mathrm{GA}=\mathrm{gestational}$ age, $\mathrm{MW}=$ maternal weight

majority of the cases the ultrasound examination was performed at a maximum of 1 day before delivery (56.6\%). $34.3 \%$ of the examinations were made $2-5$ days before delivery and $9.1 \%$ on days 6 or 7 prior to birth.

\section{Mean percentage error and}

mean absolute percentage error

The MPE and MAPE values for the 35 employed formulae are listed in Table 2. The largest overestimation was seen for the Birnholz formula with an MPE of $-12.2 \%$ while the clearest underestimation was found with the Mielke I formula $(\mathrm{MPF}=46.0 \%)$. It should be emphasised that the lowest percentage errors were found for the Hadlock III formula (0.8\%) and the Hadlock $\mathrm{V}$ formula $(-0.8 \%)$. In a comparison of all formulae the standard deviations varied between $6.4 \%$ (Schild II) and $16.4 \%$ (Hadlock IV).

20 formulae (Halaska, Schild I, Shinozuka, Sabbagha, Hadlock III, Hadlock I, Ott, Hadlock V, Combs, Hadlock II, Merz I, Rose-McCallum, Shepard, Warsof, Ferrero, Hadlock VI, Campbell, Persson,
Hansmann, Jordaan) exhibited MAPE values of $\leq 10 \%$. Of special interest is the Halaska formula that showed the best value of $6.6 \%$. Six formulae gave MAPE values in the intermediate error range of 10.1 to $\leq 15 \%$ and further 9 formulae had MAPE values in the critical region of $\geq 15.1 \%$.

- Table 3 presents the frequency distribution of differences between actual birth weight and estimated birth weight for the indivdual formulae in the weight range of $2500-4000 \mathrm{~g}$. The favourable performance of the Halaska formula is again confirmed here. With use of the Halaska formula for birth weight estimation, $43.85 \%$ of the cases lie below the $5 \%$ and $77.52 \%$ below the $10 \%$ error level. Altogether there were 22 formulae for which more than half of the estimated values showed a deviation of $\leq 10 \%$. For four formulae (Weiner II, Schild II, Mielke II and Mielke I), on the other hand, estimations of more than half of the cases gave rise to clinical questionable deviations of more than $20 \%$. 
Table 2 MPE and MAPE values including standard deviations for all 35 formulae in the birth weight range from 2500-4000 g.

\begin{tabular}{|c|c|c|c|c|c|c|}
\hline & \multicolumn{4}{|l|}{ MPE (\%) } & \multicolumn{2}{|l|}{ MAPE (\%) } \\
\hline & \multirow[t]{2}{*}{ Mean value } & \multirow[t]{2}{*}{ SD } & \multicolumn{2}{|c|}{ Confidence interval } & \multirow[t]{2}{*}{ Mean value } & \multirow[t]{2}{*}{ SD } \\
\hline & & & Lower limit & Upper limit & & \\
\hline Halaska & 0.9 & 8.1 & 0.6 & 1.2 & 6.6 & 4.8 \\
\hline Schild I & 1.9 & 8.2 & 1.6 & 2.2 & 6.8 & 5.0 \\
\hline Shinozuka & -1.5 & 8.9 & -1.8 & -1.2 & 7.2 & 5.4 \\
\hline Sabbagha & 2.8 & 8.6 & 2.5 & 3.1 & 7.3 & 5.4 \\
\hline Hadlock III & 0.8 & 9.2 & 0.5 & 1.1 & 7.4 & 5.5 \\
\hline Hadlock I & 2.5 & 8.9 & 2.2 & 2.8 & 7.5 & 5.5 \\
\hline Ott & 3.9 & 8.5 & 3.6 & 4.2 & 7.5 & 5.5 \\
\hline Hadlock V & -0.8 & 10.0 & -1.1 & -0.5 & 8.0 & 6.1 \\
\hline Combs & 5.6 & 8.1 & 5.3 & 5.9 & 8.1 & 5.7 \\
\hline Hadlock II & 3.6 & 9.6 & 3.3 & 3.9 & 8.3 & 6.1 \\
\hline MerzI & -5.0 & 9.3 & -5.3 & -4.7 & 8.4 & 6.5 \\
\hline Rose-McCallum & -1.9 & 10.5 & -2.2 & -1.6 & 8.5 & 6.5 \\
\hline Shepard & -1.9 & 10.6 & -2.2 & -1.6 & 8.5 & 6.6 \\
\hline Warsof & 3.2 & 10.1 & 2.9 & 3.5 & 8.5 & 6.3 \\
\hline Ferrero & -3.5 & 10.3 & -3.8 & -3.2 & 8.6 & 6.6 \\
\hline Hadlock VI & 6.2 & 8.7 & 5.9 & 6.5 & 8.7 & 6.2 \\
\hline Campbell & 5.0 & 9.9 & 4.7 & 5.5 & 8.9 & 6.7 \\
\hline Persson & 6.4 & 9.0 & 6.1 & 6.7 & 9.0 & 6.4 \\
\hline Hansmann & -7.3 & 9.1 & -7.6 & -7.0 & 9.3 & 7.1 \\
\hline Jordaan & 5.0 & 10.6 & 4.7 & 5.3 & 9.5 & 6.9 \\
\hline Schillinger & -9.6 & 9.3 & -9.9 & -9.3 & 10.9 & 7.8 \\
\hline Vinzeleos & -7.0 & 12.9 & -7.4 & -6.6 & 11.5 & 9.1 \\
\hline Higginbottom & 9.2 & 13.1 & 8.8 & 9.6 & 13.1 & 9.2 \\
\hline Hadlock IV & 3.4 & 16.4 & 2.9 & 3.9 & 13.3 & 10.0 \\
\hline Weiner I & 12.9 & 8.9 & 12.6 & 13.2 & 13.6 & 7.7 \\
\hline Birnholz & -12.2 & 11.7 & -12.6 & -11.8 & 13.9 & 9.8 \\
\hline Merz II & -11.3 & 16.1 & -11.8 & -10.8 & 15.4 & 12.2 \\
\hline Siemer & 16.7 & 6.6 & 16.5 & 16.9 & 16.8 & 6.4 \\
\hline Thurnau & 17.0 & 7.0 & 6.8 & 7.2 & 17.1 & 6.8 \\
\hline Scott & 17.6 & 6.8 & 17.4 & 17.8 & 17.6 & 6.7 \\
\hline Woo & 17.9 & 7.3 & 17.7 & 18.1 & 18.0 & 7.1 \\
\hline Weiner II & 19.7 & 9.9 & 19.4 & 20.0 & 20.1 & 9.1 \\
\hline Schild II & 23.0 & 6.4 & 22.8 & 23.2 & 23.0 & 6.3 \\
\hline Mielke II & 25.8 & 10.7 & 25.5 & 26.1 & 25.9 & 10.5 \\
\hline Mielke I & 46.0 & 8.1 & 45.7 & 46.3 & 46.0 & 8.1 \\
\hline
\end{tabular}

\section{Regression analysis between estimation error and actual birth weight}

The determination of regression lines was able to demonstrate by means of graphic plots the variance of the deviations between estimated and actual birth weights over the entire weight range. O Fig. 1 shows the 16 formulae that exhibited an intersection with the ideal regression line $(\mathrm{x}$ [actual birth weight] $=\mathrm{y}$ [estimated birth weight]). A common feature of all formulae is that they move up from a region of weight overestimation in the lower range to a region of underestimation.

- Fig. 2 shows the distribution of 5 formulae that always resulted in overestimations of the birth weight. Estimations according to the Rose-McCullum formula were nearest and almost parallel to the ideal line. $\odot$ Fig. 3 , on the other hand, illustrates the distribution of the 14 formulae that always led to an underestimation of the birth weight. Markedly different courses can be clearly seen here. Whereas in the lower weight range the formula according to Jordaan is closest to the ideal this is true for the Schild II formula in the upper weight range.

\section{Discussion}

In the present study we have, on the basis of measurements of 3416 foetuses, shown that the smallest MPEs can be obtained with the Hadlock III and V formulae $(0.8 \%$, SD $9.2 \%$ or, respectively, $-0.8 \%$, SD $10.0 \%$ ). The lowest absolute error (6.6\%) as well as the most favourable frequency distribution for cases with lower than $5 \%$ and $10 \%$ errors ( 43.9 and 77.5 ) were seen for the Halaska formula. This corresponds to the expected values from comparable preliminary work. The majority of the weight estimation formulae were developed for average infants weighing between 2500-4000 g and exhibited thereby a relatively low absolute percentage error of between $6-10 \%$, just as in our series [40-42]. Merely 5 formulae consistently showed overestimations of weight. 14 formulae underestimated the foetal weight over the entire weight range, 16 did so in the upper weight region.

There are numerous possibilities to improve the weight estimations. With regard to the accuracy of sonographic measurements, several studies have shown that practical sonographic experience or, respectively, targeted training on patients or simulators can reduce the errors $[41,43]$. Also a time window between measurements and delivery of $\leq 7$ days can help to reduce errors [44]. Another option, especially for heavier infants, is an optimisation 
Table 3 Frequency distribution between estimated and actual birth weights in the birth weight range of 2500-4000 g.

\begin{tabular}{|c|c|c|c|c|}
\hline \multirow[t]{2}{*}{ Formula } & \multicolumn{4}{|c|}{ Difference between actual and estimated birth weight less than: } \\
\hline & 5 percent & 10 percent & 20 percent & 30 percent \\
\hline Halaska & $43.85 \%$ & $77.52 \%$ & $98.77 \%$ & $100.00 \%$ \\
\hline Schild I & $43.62 \%$ & $76.38 \%$ & $98.27 \%$ & $99.97 \%$ \\
\hline Shinozuka & $41.98 \%$ & $73.07 \%$ & $97.51 \%$ & $99.77 \%$ \\
\hline Sabbagha & $41.31 \%$ & $71.72 \%$ & $97.98 \%$ & $99.88 \%$ \\
\hline Hadlock III & $40.28 \%$ & $71.49 \%$ & $97.19 \%$ & $99.82 \%$ \\
\hline Hadlock I & $40.60 \%$ & $71.46 \%$ & $97.34 \%$ & $99.94 \%$ \\
\hline Ott & $39.99 \%$ & $70.32 \%$ & $97.28 \%$ & $99.91 \%$ \\
\hline Hadlock V & $37.76 \%$ & $68.68 \%$ & $95.52 \%$ & $99.56 \%$ \\
\hline Combs & $36.15 \%$ & $67.10 \%$ & $96.34 \%$ & $99.94 \%$ \\
\hline Hadlock II & $36.48 \%$ & $65.49 \%$ & $95.64 \%$ & $99.74 \%$ \\
\hline Merz I & $37.88 \%$ & $66.04 \%$ & $94.06 \%$ & $99.39 \%$ \\
\hline Rose-McCallum & $35.63 \%$ & $65.52 \%$ & $93.97 \%$ & $99.44 \%$ \\
\hline Shepard & $35.98 \%$ & $65.66 \%$ & $93.91 \%$ & $99.06 \%$ \\
\hline Ferrero & $35.51 \%$ & $64.17 \%$ & $93.53 \%$ & $99.36 \%$ \\
\hline Hadlock VI & $32.96 \%$ & $62.76 \%$ & $94.67 \%$ & $99.80 \%$ \\
\hline Campbell & $34.75 \%$ & $62.09 \%$ & $93.03 \%$ & $99.33 \%$ \\
\hline Persson & $32.90 \%$ & $60.69 \%$ & $93.62 \%$ & $99.82 \%$ \\
\hline Hansmann & $34.02 \%$ & $61.62 \%$ & $91.36 \%$ & $98.59 \%$ \\
\hline Jordaan & $32.11 \%$ & $58.96 \%$ & $90.95 \%$ & $99.33 \%$ \\
\hline Schillinger & $27.20 \%$ & $52.78 \%$ & $86.74 \%$ & $97.80 \%$ \\
\hline Vinzeleos & $28.37 \%$ & $52.69 \%$ & $83.55 \%$ & $95.70 \%$ \\
\hline Higginbottom & $22.72 \%$ & $43.41 \%$ & $76.49 \%$ & $95.49 \%$ \\
\hline Hadlock IV & $21.98 \%$ & $44.15 \%$ & $76.87 \%$ & $93.88 \%$ \\
\hline Weiner I & $15.13 \%$ & $35.51 \%$ & $78.60 \%$ & $98.19 \%$ \\
\hline Birnholz & $21.02 \%$ & $40.63 \%$ & $75.09 \%$ & $92.83 \%$ \\
\hline Merz II & $21.75 \%$ & $40.31 \%$ & $69.85 \%$ & $88.00 \%$ \\
\hline Siemer & $4.42 \%$ & $16.10 \%$ & $66.63 \%$ & $99.24 \%$ \\
\hline Thurnau & $4.33 \%$ & $15.37 \%$ & $65.13 \%$ & $97.95 \%$ \\
\hline Woo & $3.60 \%$ & $13.55 \%$ & $59.69 \%$ & $95.84 \%$ \\
\hline Weiner II & $5.56 \%$ & $14.72 \%$ & $48.71 \%$ & $86.24 \%$ \\
\hline Schild II & $0.50 \%$ & $2.49 \%$ & $30.85 \%$ & $86.56 \%$ \\
\hline Mielke II & $2.72 \%$ & $7.52 \%$ & $28.69 \%$ & $64.08 \%$ \\
\hline Mielke I & $0.00 \%$ & $0.00 \%$ & $0.09 \%$ & $3.28 \%$ \\
\hline
\end{tabular}

of the weight estimation through a combination of ultrasound findings with maternal and pregnancy-specific parameters such as gestational age, parity, gender of the foetus, and maternal height or weight. The presumed benefit of such an elaborate procedure is, however, a subject of controversial discussion in the current literature [45-47]. Nevertheless, there is consensus that maternal obesity increases the estimation errors $[48,49]$.

Ultimately, the estimation errors of sonographic formulae must be considered as being intrinsic to the method. In a study of 628 new-born infants, Kehl et al. could reduce the systematic error to a minimum by means of postnatally performed measurements. Even so, the MPEs of the employed formulae were between 7.42 and $8.77 \%$. The proportion of estimations with an error of under $10 \%$ amounted to between 74.6 and $81.3 \%$. Under consideration of the $95 \%$ limits of agreement, the estimations were in a range of $\pm 500 \mathrm{~g}$. These key data for optimal weight estimations are in agreement with our results when using the best formulae such as those according to Halaska or Hadlock.

Our data show that many formulae exhibit a variable susceptibility to error within the normal weight range. This observation supports the attempts of current research groups to use a twostep procedure for weight estimations. In a first such step the weight range, for example, is delineated by measurement of the $\mathrm{AC}$ and the formula chosen in dependence on this result. It has been demonstrated that those formulae that had been specifi- cally developed for foetuses with an abdominal circumference of less than $290 \mathrm{~mm}$ exhibited a significantly better MAPE (7.13$7.61 \%$ ) and markedly more measurements with an error of less than $10 \%$ in comparison with the Warsof and Hadlock formulae [50]. An analogous result has been determined for infants with an AC greater than $360 \mathrm{~mm}$ [51]. The so-called Zürich method follows a similar strategy. In this case, the product of the AC and the FL is calculated. When this value is $<24600$ the Hadlock formula is used, for larger values the Merz formula [52]. Our data confirm that in the upper weight range the Merz formula enables a better weight estimation than the Hadlock formula.

A further strategy for improvement involves the implementation of 3D measurements, as a rule in the standardised determination of a volume from the foetal thigh region. At least in cases of manifest gestational diabetes, an improvement in weight estimation through 3D measurements seems to be possible because just in such pregnancies the soft tissue mantle does especially influence the weight of the foetus [53].

On a critical note, it must be realised that the validity of the present data is limited due to the retrospective nature of the study. The monocentric data acquisition represents a further limitation. However, this is relativised somewhat by the large number of participating investigators with varying degrees of training and experience. 


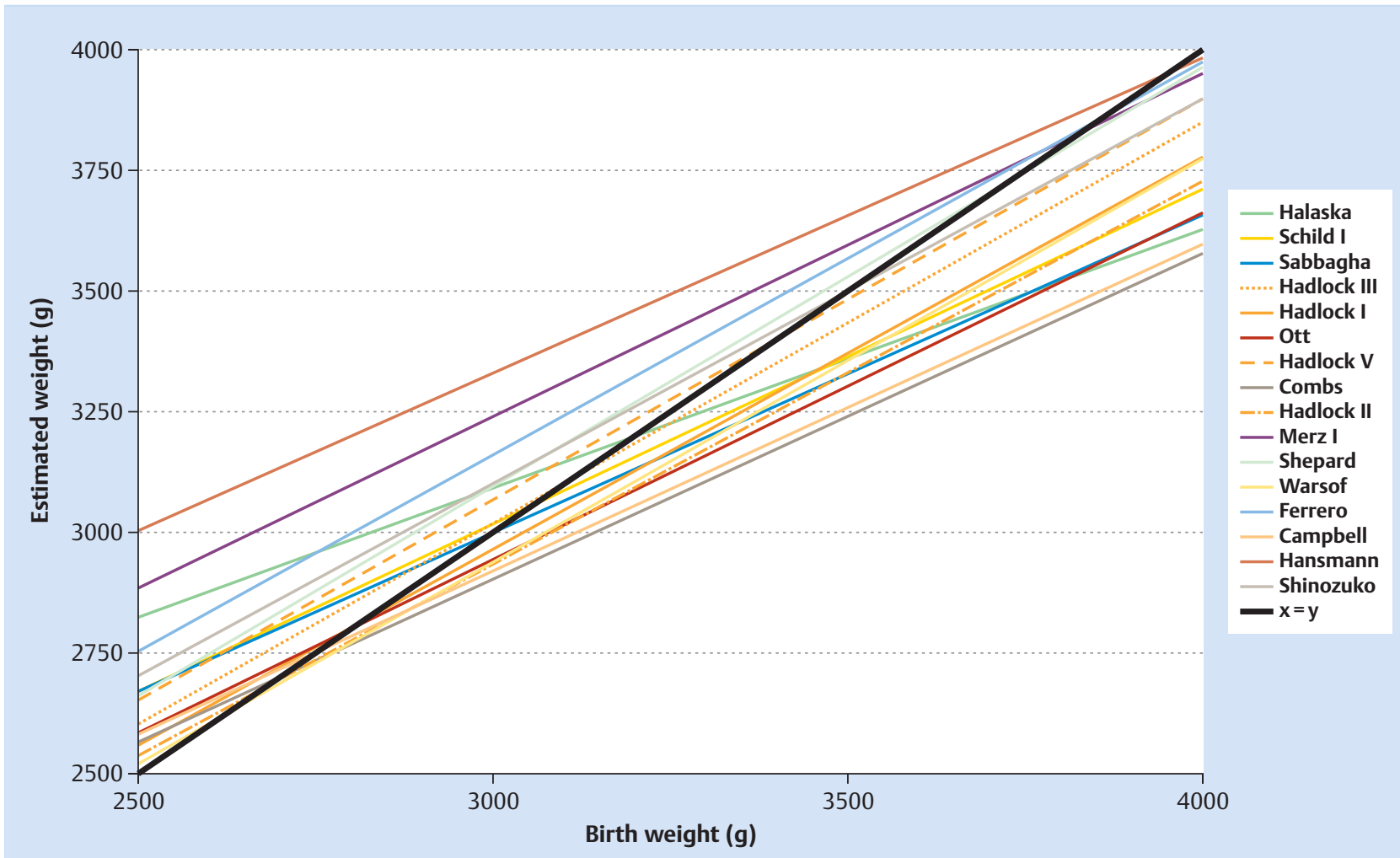

Fig. 1 Actual and estimated birth weights. The listed regression formulae have an intersection with the ideal regression formula $y=x$ for birth weights between 2500 and $4000 \mathrm{~g}$.

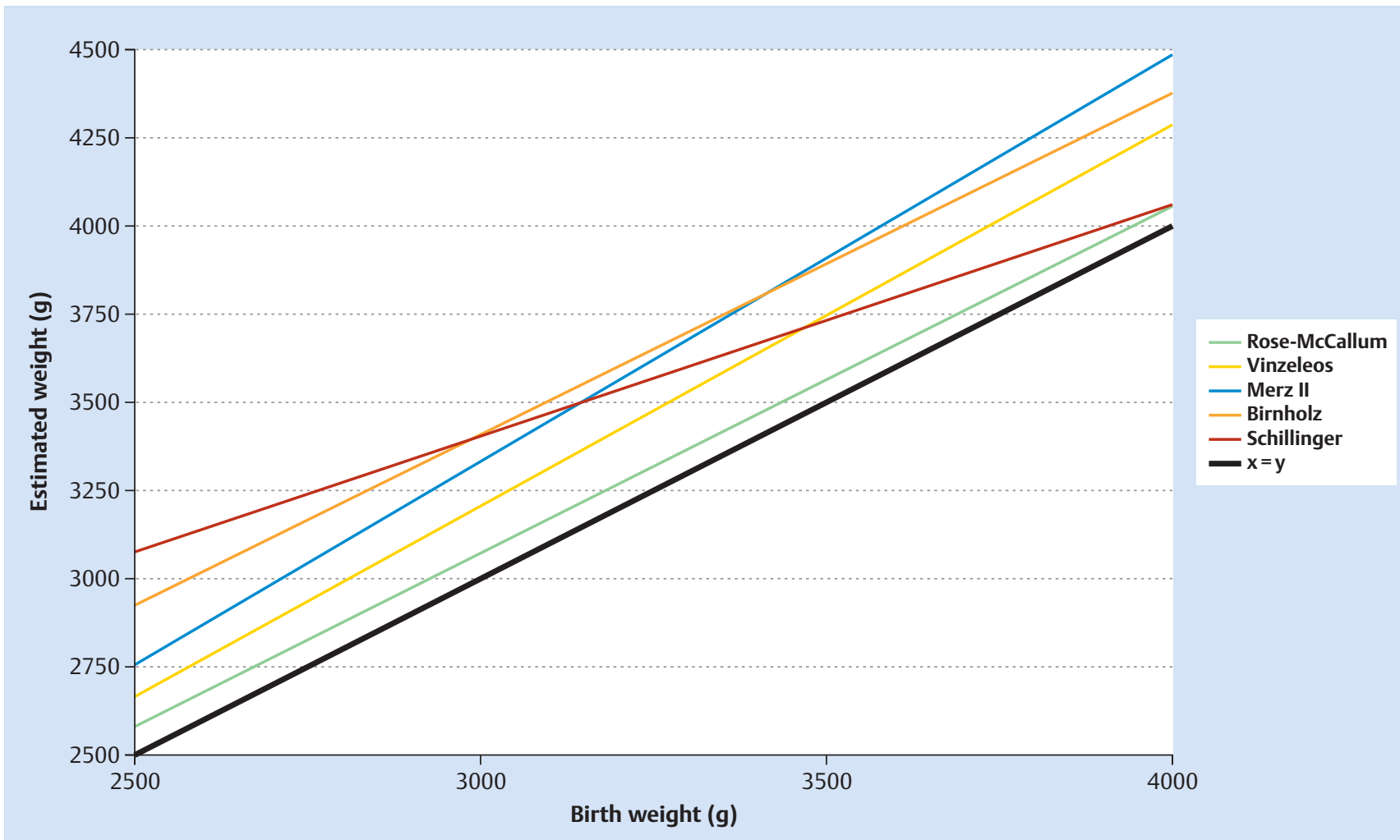

Fig. 2 Actual and estimated birth weights. In the weight range from 2500 to $4000 \mathrm{~g}$ the listed regression formulae do not have an intersection point with the ideal regression formula $y=x$. On average the estimated weight was higher than the actual birth weight. 


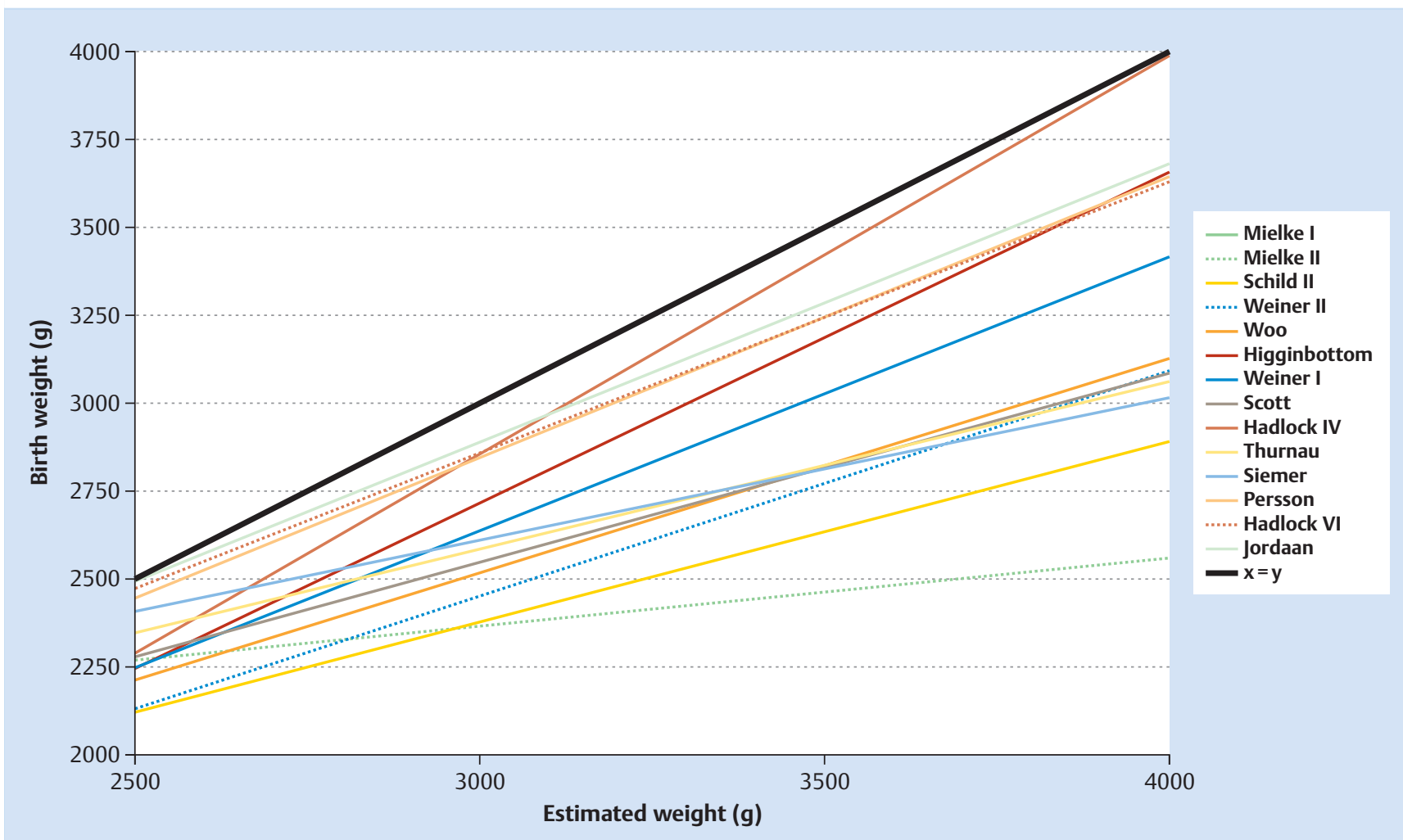

Fig. 3 Actual and estimated birth weights. In the weight range from 2500 to $4000 \mathrm{~g}$ the listed regression formulae do not have an intersection point with the ideal regression formula $y=x$. On average the estimated weight was lower than the actual birth weight. The plot according to the Mielke I formula lies below the illustrated region.

\section{Conclusions}

$\nabla$

When judged by the MPE and MAPE results, the formulae according to Hadlock and Halaska exhibit the lowest errors. Most of the formulae tend to underestimate the weight to varying degress depending on the weight class. This supports current efforts to apply a two-step procedure.

\section{Conflict of Interest}

$\nabla$

The authors declare that they have no conflicts of interest.

\section{References}

1 Willocks J, Donald I, Duggan TC et al. Foetal cephalometry by ultrasound. J Obstet Gynaecol Br Commonw 1964; 71: 11-20

2 Loeffler FE. Clinical foetal weight prediction. J Obstet Gynaecol Br Commonw 1967; 74: 675-677

3 Warsof SL, Gohari P, Berkowitz RL et al. The estimation of fetal weight by computer-assisted analysis. Am J Obstet Gynecol 1977; 128: 881892

4 Hadlock FP, Harrist RB, Sharman RS et al. Estimation of fetal weight with the use of head, body, and femur measurements-a prospective study. Am J Obstet Gynecol 1985; 151: 333-337

5 Hadlock FP, Harrist RB, Carpenter RJ et al. Sonographic estimation of fetal weight. The value of femur length in addition to head and abdomen measurements. Radiology 1984; 150: 535-540

6 Hoopmann M, Bernau B, Hart $N$ et al. Do specific weight formulas for fetuses $\leq 1500$ g really improve weight estimation? Ultraschall in Med 2010; 31: 48-52
7 Hoopmann M, Abele $H$, Wagner $N$ et al. Performance of 36 different weight estimation formulae in fetuses with macrosomia. Fetal Diagn Ther 2010; 27: 204-213

8 Abele H, Hoopmann M, Wagner $N$ et al. Accuracy of sonographic fetal weight estimation of fetuses with a birth weight of $1500 \mathrm{~g}$ or less. Eur J Obstet Gynecol Reprod Biol 2010; 153: 131-137

9 American College of Obstetricians and Gynecologists. ACOG Practice bulletin no. 134: fetal growth restriction. Obstet Gynecol 2013; 121: 1122-1133

10 Gyurkovits Z, Kálló K, Bakki J et al. Neonatal outcome of macrosomic infants: an analysis of a two-year period. Eur J Obstet Gynecol Reprod Biol 2011; 159: 289-292

11 Henriksen T. The macrosomic fetus: a challenge in current obstetrics. Acta Obstet Gynecol Scand 2008; 87: 134-145

12 Schmidt $U$, Temerinac $D$, Bildstein $K$ et al. Finding the most accurate method to measure head circumference for fetal weight estimation. Eur J Obstet Gynecol 2014; 178: 153-156

13 Birnholz JC. An algorithmic approach to accurate ultrasonic fetal weight estimation. Invest Radiol 1986; 21: 571-576

14 Combs CA, Jaekle RK, Rosenn B et al. Sonographic estimation of feta weight based on a model of fetal volume. Obstet Gynecol 1993; 82: 365-370

15 Campbell S, Wilkin D. Ultrasonic measurement of fetal abdomen circumference in the estimation of fetal weight. Br J Obstet Gynaecol 1975; 82: 689-697

16 Ferrero A, Maggi E, Giancotti A et al. Regression formula for estimation of fetal weight with use of abdominal circumference and femur length: a prospective study. J Ultrasound Med 1994; 13: 823-833

17 Halaska MG, Vlk R, Feldmar P et al. Predicting term birth weight using ultrasound and maternal characteristics. Eur J Obstet Gynecol 2006; 128: $231-235$

18 Hansmann $M$, Schuhmacher $H$, Voigt $U$. Mehrparametrische nicht lineare Gewichtsschätzung mittels Ultraschall unter Berücksichtigung des Gestationsalters. In: Kratochwil A, Reinold E, Hrsg. Ultraschalldiagnostik. Stuttgart: Thieme; 1978 
19 Hart NC, Hilbert A, Meurer B et al. Macrosomia: a new formula for optimized fetal weight estimation. Ultrasound Obstet Gynecol 2010; 35: $42-47$

20 Higginbottom J. Estimation of fetal weight. Ultrasound Med Biol 1977; 3: 59

21 Jordaan HV, Dunn $L J$. A new method of evaluating fetal growth. Obstet Gynecol 1978; 51: 659-665

22 Merz E, Lieser H, Schicketanz KH et al. [Intrauterine fetal weight assessment using ultrasound. A comparison of several weight assessment methods and development of a new formula for the determination of fetal weight]. Ultraschall Med 1988; 9: 15-24

23 Marsál K. Antenatal diagnosis of intrauterine growth retardation by ultrasound. Int J Technol Assess Health Care 1992; 8 (Suppl. 1): 160-169

24 Mielke G, Pietschbreitfeld B, Salinas $R$ et al. A new formula for prenatal ultrasonographic weight estimation in extremely preterm fetuses. Gynecol Obstet Invest 1995; 40: 84-88

25 Mielke G, Pietschbreitfeld B, Regele B et al. An accurate method for sonographic estimation of the weight of very preterm fetuses. Gynecol Obstet Invest 1997; 43: 98-103

26 Ott WJ, Doyle S, Flamm S et al. Accurate ultrasonic estimation of fetal weight. Prospective analysis of new ultrasonic formulas. Am J Perinatol 1986; 3: 307-310

27 Rose BI, McCallum WD. A simplified method for estimating fetal weight using ultrasound measurements. Obstet Gynecol 1987; 69: 671-675

28 Sabbagha R, Minogue J, Tamura $R$ et al. Estimation of birth-weight by use of ultrasonographic formulas targeted to large-for-gestationalage, appropriate-for-gestational-age, and small-for-gestational-age fetuses. Am J Obstet Gynecol 1989; 160: 854-862

29 Schild RL, Sachs C, Fimmers $R$ et al. Sex-specific fetal weight prediction by ultrasound. Ultrasound Obstet Gynecol 2004; 23: 30-35

30 Schillinger $H$, Müller R, Wode J et al. [Intrauterine weight determination of the fetus using ultrasonics]. Arch Gynakol 1975; 219: 399-401

31 Scott F, Beeby P, Abbott J et al. New formula for estimating fetal weight below $1000 \mathrm{~g}$ : comparison with existing formulas. J Ultrasound Med 1996; 15: 669-672

32 Shepard MJ, Richards VA, Berkowitz RL et al. An evaluation of two equations for predicting fetal weight by ultrasound. Am J Obstet Gynecol 1982; 142: 47-54

33 Shinozuka N, Okai T, Kohzuma S et al. Formulas for fetal weight estimation by ultrasound measurements based on neonatal specific gravities and volumes. Am J Obstet Gynecol 1987; 157: 1140-1145

34 Siemer J, Hilbert A, Hart $N$ et al. A new sonographic weight formula for fetuses. Ultraschall in Med 2009; 30: 47-51

35 Thurnau GR, Tamura RK, Sabbagha $R$ et al. A simple estimated fetal weight equation based on real-time ultrasound measurements of fetuses less than thirty-four weeks' gestation. Am J Obstet Gynecol 1983; 145: 557-561

36 Vintzileos AM, Campbell WA, Rodis JF et al. Fetal weight estimation formulas with head, abdominal, femur, and thigh circumference measurements. Am J Obstet Gynecol 1987; 157: 410-414
37 Weiner CP, Sabbagha RE, Vaisrub $N$ et al. Ultrasonic fetal weight prediction: role of head circumference and femur length. Obstet Gynecol 1985; 65: 812-817

38 Woo J, Wan M. An evaluation of fetal weight prediction using a simple equation containing the fetal femur length. J Ultrasound Med 1986; 5 : 453-457

39 Schild RL, Fell K, Fimmers $R$ et al. A new formula for calculating weight in the fetus of < or $=1600 \mathrm{~g}$. Ultrasound Obstet Gynecol 2004; 24: 775780

40 Melamed N, Yogev Y, Meizner I et al. Sonographic fetal weight estimation: which model should be used? J Ultrasound Med 2009; 28: 617629

41 Siemer J, Egger $N$, Hart $N$ et al. Fetal weight estimation by ultrasound: comparison of 11 different formulae and examiners with differing skill levels. Ultraschall Med 2008; 29: 159-164

42 Nahum GG, Stanislaw H. Ultrasonographic prediction of term birth weight: How accurate is it? Am J Obstet Gynecol 2003; 188: 566-574

43 Haist M, Schauf B, Kagan KO et al. Verbesserung der Ergebnisqualität durch standardisiertes Training am Ultraschallsimulator. Geburtsh Frauenheilk 2010; 70: 844-848

44 Faschingbauer F, Raabe E, Heimrich J et al. Accuracy of sonographic fetal weight estimation: influence of the scan-to-delivery interval in combination with the applied weight estimation formula. Arch Gynecol Obstet 2016; 294: 487-493

45 Nahum GG, Stanislaw H. Fetal macrosomia is predicted earlier by combination birth-weight estimation methods than by ultrasound alone. Ultrasound Obstet Gynecol 2009; 34: 122

46 Mazouni C, Rouzier R, Ledu R et al. Development and internal validation of a nomogram to predict macrosomia. Ultrasound Obstet Gynecol 2007; 29: 544-549

47 Balsyte D, Schäffer L, Burkhardt T et al. Sonographic prediction of macrosomia cannot be improved by combination with pregnancy-specific characteristics. Ultrasound Obstet Gynecol 2009; 33: 453-458

48 Aksoy $H$, Aksoy U, Karadag OI et al. Influence of maternal body mass index on sonographic fetal weight estimation prior to scheduled delivery. J Obstet Gynaecol Res 2015; 41: 1556-1561

49 Heer IM, Kumper C, Vogtle $N$ et al. Analysis of factors influencing the ultrasonic fetal weight estimation. Fetal Diagn Ther 2008; 23: 204-210

$50 \mathrm{Kehl}$ S, Koerber C, Hart $N$ et al. New sonographic method for fetuses with small abdominal circumference improves fetal weight estimation. Ultraschall Med 2012; 33: 469-473

51 Kehl S, Koerber C, Hart $N$ et al. New sonographic method for fetuses with a large abdominal circumference improves fetal weight estimation. Ultraschall Med 2012; 33: 265-269

52 Balsyte D, Schäffer L, Zimmermann $R$ et al. Optimized sonographic weight estimation of fetuses over $3500 \mathrm{~g}$ using biometry-guided formula selection. Ultraschall Med 2015; [Epub ahead of print]

53 Pagani G, Palai N, Zatti S et al. Fetal weight estimation in gestational diabetic pregnancies: comparison between conventional and three-dimensional fractional thigh volume methods using gestation-adjusted projection. Ultrasound Obstet Gynecol 2014; 43: 72-76 